\title{
Determinan Ketimpangan Indeks Pembangunan Manusia di Provinsi Jambi
}

\author{
Arniwita $^{1 *}$, Deka Veronica ${ }^{2}$, Ahmad Soleh $^{3}$ \\ ${ }^{1,2,3}$ Universitas Muhammadiyah Jambi \\ *Correspondence email: mas.soleh@yahoo.com
}

\begin{abstract}
The Human Development Index (HDI) is an index to measure human achievement and is one of the indicators used in looking at people's well-being in a region. The higher the HDI value in a region, the better the level of welfare in the region. So often HDI is considered to have been able to represent the welfare level of the population, because in the HDI includes elements that include economic and noneconomic variables. Non-economic variables are measured from the level of public education and the degree of public health. While economic variables are measured from income levels indicating people's purchasing power, the three are related to each other. However, if you look at the conditions in Jambi Province, there is an interesting phenomenon where the development of the government does not or lack a real impact on the improvement of the Human Development Index $(H D I)$, so it is necessary to do this research. The purpose of this study is to analyze the inequality, influence and relationship of the variables of the human development index which includes Gross Regional Domestic Product (GRDP) per capita, the number of medical personnel, the number of basic health facilities, the number of poor people as well as the number of teachers in public elementary schools as dependent variables with the human development index (HDI) as dependent variables. The data analysis method used in this study is a qualitative and qualitative descriptive method of explanatory properties, using sekuder data in the period 2008-2017. The data analysis tool used in this study uses the usual Weighted Coefficient of Variation (CVw) method for the first problem, the subsequent regression of the data panel for the second problem and the person correlation for the third problem. The hypothesis test in this study shows that there is inequality in IPM-forming variables in Jambi Province, further influence and significant relationship between ipm-forming variable inequality and HDI in Jambi Province.
\end{abstract}

Keywords: HDI Forming Variables, HDI

\section{Pendahuluan}

Pembanguan manusia adalah proses memperluas pilihan penduduk (Enlarging the choices of people) yang dapat ditumbuh kembangkan melalui pemberdayaan (UNDP, 2017). Pemberdayaan dimaksud adalah peningkatan kemampuan dasar manusia seperi peningkatan kesehatan, pengetahuan dan keterampilan yang diukur dengan Indeks Pembangunan Manusia (IPM). IPM merupakan indikator yang digunakan untuk mengukur kualitas dari pembangunan ekonomi yakni derajat perkembangan manusia. IPM mempunyai tiga unsur pokok yaitu kesehatan, pendidikan yang dan standar kehidupan yang ketiganya saling terkait satu sama lainnya. Fokus tentang pembangunan manusia berawal dari munculnya teori investasi dan kapital yang menjelaskan pentingnya SDM yang memainkan peranan vital dalam pembangunan ekonomi. IPM dianggap telah dapat mewakili tingkat kesejahteraan penduduk, karena sebagaimana dimaklumi bahwa IPM mencakup unsur analisis yang meliputi variabel ekonomi dan non ekonomi. Variabel non ekonomi diukur dari tingkat pendidikan masyarakat, derajat kesehatan masyarakat sedangkan variabel ekonomi dilihat dari pendapatan yang menunjukkan daya beli masyarakat.

Dalam hal ini Provinsi Jambi merupakan provinsi yang fokus dalam pembangunan manusia, namun dalam pelaksanaannya tidak serta merta mampu meningkatkan pembangunan manusia sebagai proksi peningkatan kesejahteraan manusia. Menurut Tabhrany (1996) untuk meningkatkan daya saing penduduk pada abad 21 perlu dilakukan perbaikan pendidikan, keterampilan, disiplin, dan modal kerja, kesehatan penduduk. Oleh karena itu perlu dilakukan penelitian yang mendalam terkait dengan determinan rendahnya peningkatan indeks pembangunan manusia dan faktor yang menjadi penyebab rendahnya IPM di Provinsi Jambi. Adapun tujuan dari penelitian ini adalah Menganalisis tingkat ketimpangan dan pengaruh variabel-variabel pembentuk IPM terhadap nilai IPM di Provinsi Jambi.

\section{Indeks Pembangunan Manusia}

Indeks Pembangunan Manusia (IPM) merupakan indikator komposit tunggal yang digunakan untuk mengukur pencapaian pembangunan manusia yang telah dilakukan di suatu wilayah. Sementara menurut BPS (2001) IPM adalah indeks komposit, yang hanya mencakup tiga dimensi pembangunan manusia yang dianggap memiliki nilai strategis. Ketiga dimensi itu adalah usia hidup (longevity), pengetahuan (knowledge), dan standar hidup layak (decent living). Pemilihan dimensi itu sejalan dengan definisi pembangunan manusia. IPM digunakan untuk mengklasifikasikan apakah suatu negara termasuk kategori negara maju, negara berkembang atau negara terbelakang. IPM digunakan untuk merefleksikan sejauh mana upaya dan kebijakan yang dilakukan dalam kerangka pembangunan manusia, khususnya melalui upaya pengentasan kemiskinan, peningkatan kualitas sumberdaya manusia, dan 
partisipasi penduduk dalam pembangunan. BPS et al (2001) menyebutkan bahwa menurut skala internasional indeks pembangunan manusia dikategorikan menjadi 3 (tiga) kategori dan 4 (empat) sub kategori sebagai berikut:

Tabel 1.

Kategori dan Sub Kategori Indeks Pembangunan Manusia Menurut Skala Internasional

\begin{tabular}{cccc}
\hline No. & Kategori & Sub kategori & Angka IPM \\
\hline 1 & Tinggi & Tinggi & $80,00-100$ \\
2 & Menengah & Menengah Atas & $66,00-79,99$ \\
3 & Rendah & Menengah Bawah & $50,00-65,99$ \\
\hline
\end{tabular}

Sumber: Laporan Pembangunan Manusia Indonesia Tahun 2001

Variabel pembentuk IPM dalam penelitian ini adalah PDRB perkapita, jumlah tenaga medis, jumlah fasilitas dasar kesehatan (puskesmas), jumlah penduduk miskin, dan jumlah guru sekolah dasar negeri.

\section{Metode}

Metode dalam penelitian ini adalah deskriptif kualitatif dan kuantitatif dengan pendekatan library research. Penelitian ini menggunakan data sekunder yang bersumber dari Badan Pusat Statistik (BPS), Bappeda, Dinas Pendidikan, dan Dinas Kesehatan dan literatur serta jurnal yang berkaitan dengan penelitian. Rencana penelitian dilakukan di 11 kabupate/kota yang ada di Provinsi Jambi selama periode tahun 2007-2017. Untuk menjawab permasalahan pertama yaitu tingkat ketimpangan variabel-variabel pembentuk IPM digunakan model analisis Weighted Coefficient of Variation (CVw) biasa, yaitu:

$\mathrm{VW}=\frac{\sqrt{\sum_{i-1}^{n}(Y i-Y)^{2}\left(\frac{f i}{n}\right)}}{Y}$

Dimana: $Y i=$ PDRB perkapita Kab/Kota i; $Y=$ PDRB perkapita Provinsi Jambi; fi = Jumlah penduduk Kabupaten kei; $\mathrm{n}=$ Jumlah Penduduk Provinsi Jambi

Untuk menganalisis permasalahan kedua yaitu berapa besar pengaruh variabel pembentuk IPM terhadap IPM maka digunakan model regresi data panel dengan formulasi sebagai berikut:

$\mathrm{Y}_{\mathrm{t}}=\beta_{\mathrm{o}}+\beta_{1} \mathrm{X}_{\mathrm{t} 1}+\beta_{2} \mathrm{X}_{\mathrm{t} 2}+\beta_{3} \mathrm{X}_{\mathrm{t} 3}+\beta_{4} \mathrm{X}_{\mathrm{t} 4}+\beta_{5} \mathrm{X}_{\mathrm{t} 5}+\varepsilon_{\mathrm{t}}$

Dimana: $Y_{t}=$ Indeks Pembangunan Manusia; $\beta_{o}=$ Intercept atau konstanta; $\beta_{1-7}=$ koefisien regresi; $X_{1}=$ PDRB per Kapita; $\mathrm{X}_{2} \quad=$ Jumlah Tenaga Medis Pada Fasilitas Dasar Kesehatan; $\mathrm{X}_{3}=$ Jumlah Fasilitas Dasar Kesehatan; $\mathrm{X}_{4}$ = Jumlah Penduduk Miskin; X5 = Jumlah Guru Sekolah Dasar Negeri; $t=1,2,3 \ldots .$. ,merujuk ke periode waktu tertentu; $\varepsilon_{t}=$ error. Selanjutnya dilakukan pemilihan model yang tepat dengan menggunakan uji kesesuaian model (Chow Test dan Hausman Test) dan dilanjutkan dengan uji F, uji t dan uji asumsi klasik.

\section{Hasil}

Hasil perhitungan terhadap Indeks Williamson menunjukkan bahwa secara umum angka ketimpangan variabel-variabel pembentuk IPM pada Kabupaten/Kota di Provinsi Jambi cenderung naik turun selama kurun waktu 2013-2018. Kecuali untuk variabel jumlah tenaga medis, dimana pada tahun 2018 nilai indeks nya melebihi angka satu yang berarti menunjukkan tingkat ketimpangan yang sangat ekstrim dan diluar pola umum yang ada dimana nilai CVw berkisar antara 0 dan 1.

Tabel 2

Hasil Perhitungan Weighted Coefficient of Variation (CVw)/Indeks Williamson Variabel-Variabel Pembentuk IPM di Provinsi Jambi Tahun 2013-2018

\begin{tabular}{lcccccc}
\hline \multicolumn{1}{c}{ Variabel } & $\mathbf{2 0 1 3}$ & $\mathbf{2 0 1 4}$ & $\mathbf{2 0 1 5}$ & $\mathbf{2 0 1 6}$ & $\mathbf{2 0 1 7}$ & $\mathbf{2 0 1 8}$ \\
\hline PDRB Per Kapita & 0.401 & 0.455 & 0.508 & 0.487 & 0.473 & 0.480 \\
Penduduk Miskin & 0.310 & 0.381 & 0.632 & 0.608 & 0.475 & 0.478 \\
Jumlah Tenaga Medis & 0.500 & 0.478 & 0.539 & 0.543 & 0.485 & 1.264 \\
Puskesmas & 0.313 & 0.317 & 0.183 & 0.168 & 0.154 & 0.152 \\
Jumlah Guru SD & 0.242 & 0.238 & 0.219 & 0.258 & 0.236 & 0.236 \\
\hline
\end{tabular}

Sumber: BPS, Diolah

Melalui indeks ketimpangan ini dapat mengukur salah satu aspek penting yang berkaitan dengan kualitas dari hasil pembangunan ekonomi, yakni derajat perkembangan manusia. Untuk itu perlu dilakukan upaya untuk mengurangi tingkat ketimpangan yang terjadi sehingga pembangunan ekonomi yang di cita-citakan dapat lebih cepat tercapai. Hasil pengolahan data variabel pembentuk IPM terhadap Indeks Pembangunan Manusia (IPM) di Provinsi Jambi adalah sebagai berikut: 
Tabel 3

Hasil Analisis Variabel Pembentuk IPM yang berpengaruh terhadap Indeks Pembangunan Manusia (IPM) di Provinsi Jambi

\begin{tabular}{|c|c|c|c|c|}
\hline Variable & Coefficient & Std. Error & t-Statistic & Prob. \\
\hline $\mathrm{C}(\mathrm{IPM})$ & 69.08718 & 0.531208 & 130.0566 & 0.0000 \\
\hline X1 (PDRB per Kapita) & 0.000107 & $1.44 \mathrm{E}-05$ & 7.462241 & 0.0000 \\
\hline X2 (Tenaga Medis) & 0.005854 & 0.003394 & 1.724955 & 0.0914 \\
\hline X3 (Puskesmas) & 0.063417 & 0.025449 & 2.491973 & 0.0165 \\
\hline X4 (Penduduk Miskin) & -0.022846 & 0.007511 & -3.041441 & 0.0039 \\
\hline X5 (Jumlah Guru SD) & 0.000403 & 0.000148 & 2.730063 & 0.0090 \\
\hline R-squared & 0.953354 & & & \\
\hline Adjusted R-squared & 0.938842 & & & \\
\hline S.E. of regression & 0.389483 & & & \\
\hline F-statistic & 65.69345 & & & \\
\hline Prob(F-statistic) & 0.000000 & & & \\
\hline
\end{tabular}

Sumber : Data Diolah

Sehingga hasil pengolahan jika di masukkan ke dalam model menjadi:

$\mathrm{IPM}=69.08718+0.000107$ PDRB +0.005854 Tenaga Medis +0.063417 Puskesmas -0.022846 Penduduk Miskin + 0.000403 Jumlah Guru

Koefisien determinasi $\left(\mathrm{R}^{2}\right)$ sebesar 0.953354 berarti bahwa variabel PDRB tahun sebelumnya, Variabel Tenaga Medis tahun sebelumnya, Variabel Puskesmas tahun sebelumnya, Variabel Penduduk Miskin tahun sebelumnya, dan Variabel Jumlah Guru tahun sebelumnya mampu menjelaskan impor sebesar 95,33 \% dan sisanya dapat dijelaskan oleh variabel lain.

Dilihat dari nilai F-statistik, yaitu sebesar 65.69345 yang signifikansi 0.000000, berarti bahwa secara bersamasama (simultan) variabel PDRB, variabel Tenaga Medis, variabel Puskesmas, variabel Penduduk Miskin, dan variabel Jumlah Guru yang dimasukan sebagai sebagai variabel bebas mempengaruhi variabel terikat IPM. Berikut ini hasil uji t dari masing-masing variabel bebas :

- $\quad$ PDRB Per Kapita, hasil estimasi menunjukkan bahwa angka PDRB per Kapita berpengaruh positif terhadap IPM. Nilai koefisien regresi PDRB sebesar 0.000107 berarti bahwa setiap kenaikan PDRB 1 satuan akan menyebabkan peningkatan IPM sebesar 0.000107 satuan. Hal ini berarti bahwa semakin tinggi angka pendapatan suatu daerah maka angka IPM juga akan meningkat. Dari hasil pengujian t test nilai probability $0.0000<\alpha=5 \%$ sehingga signifikan pada tingkat kepercayaan $95 \%$.

- Tenaga Medis, hasil estimasi menunjukkan bahwa jumlah tenaga medis pada fasilitas dasar kesehatan (puskesmas) berpengaruh positif terhadap IPM. Nilai koefisien regresi jumlah tenaga medis sebesar 0.005854 berarti bahwa setiap kenaikan jumlah tenaga medis 1 satuan akan menyebabkan peningkatan angka IPM sebesar 0.005854 satuan. Hal ini berarti bahwa semakin tinggi jumlah tenaga medis, maka angka IPM akan semakin meningkat. Dari hasil pengujian t test nilai probability $0.0914>5 \%$ sehingga tidak signifikan pada tingkat kepercayaan 95\%, tetapi signifikan pada $\alpha=10 \%$. Dengan kata lain variabel tenaga medis berpengaruh terhadap IPM pada tingkat kepercayaan $90 \%$.

- Puskemas, hasil estimasi menunjukkan bahwa jumlah puskesmas sebagai fasilitas dasar kesehatan memberikan pengaruh positif pada angka IPM. Nilai koefisien regresi jumlah puskesmas sebesar 0.063417 berarti bahwa jumlah puskesmas sebagai fasilitas dasar mengalami kenaikan 1 satuan akan menyebabkan terjadinya peningkatan angka IPM sebesar 0.063417 satuan. Hal ini berarti bahwa semakin tinggi jumlah puskesmas maka akan semakin meningkat angka IPM. Dari hasil pengujian t test nilai probability $0.0165<5 \%$ signifikan pada tingkat kepercayaan 95\%. Dengan kata lain secara parsial variabel jumlah puskesmas sebagai fasilitas dasar kesehatan berpengaruh terhadap angka IPM dan signifikan.

- Penduduk Miskin, hasil estimasi menunjukkan bahwa jumlah penduduk miskin berpengaruh negative terhadap angka IPM. Nilai koefisien regresi penduduk miskin sebesar -0.022846 berarti bahwa setiap kenaikan angka penduduk miskin sebesar 1 satuan akan menyebabkan penurunan angka IPM sebesar 0.022846 satuan. Hal ini berarti bahwa semakin tinggi jumlah penduduk miskin, maka akan menurunkan angka IPM. Dari hasil pengujian t test nilai probability $0.0039<5 \%$ signifikan pada tingkat kepercayaan $95 \%$. Dengan kata lain secara parsial variabel jumlah penduduk miskin berpengaruh terhadap angka IPM dan signifikan.

- Jumlah Guru, hasil estimasi menunjukkan bahwa jumlah guru pada sekolah dasar berpengaruh positif terhadap angka IPM. Nilai koefisien jumlah guru sebesar 0.000403 berarti bahwa setiap peningkatan jumlah guru 1 satuan akan menyebabkan peningkatan angka IPM sebesar 0.000403 satuan. Hal ini berarti bahwa semakin tinggi jumlah guru maka akan meningkatkan angka IPM. Dari hasil pengujian t test nilai probability $0.0090<5 \%$ signifikan pada tingkat kepercayaan 95\%. Dengan kata lain secara parsial variabel jumlah guru pada sekolah 
negeri berpengaruh terhadap angka IPM dan signifikan.

\section{Simpulan}

Dari hasil peneitian ini maka dapat disimpulkan sebagai berikut:

1. Masih tingginya tingkat ketimpangan dari variabel pembentuk IPM di Kabupaten/kota di Provinsi Jambi.

2. Variabel PDRB, Tenaga Medis, jumlah Puskesmas, Jumlah guru pada SD berpengaruh positif terhadap peningkatan IPM sementara jumlah penduduk miskin berpengaruh negatif terhadap variabel pembentuk IPM.

\section{Daftar Pustaka}

Thabrany, Hasbullah, 2005, Pendanaan Kesehatan dan Alternatif Mobilisasi Dana Kesehatan di Indonesia, Jakarta, Raja Grafindo Persada, 2005.

United Nation Developmen Programme. (2017) Human development Report. 